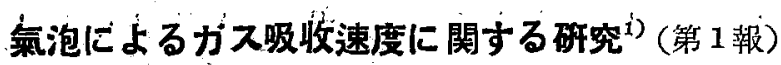

大竹侮焳 ${ }^{2}$

\section{梗概}

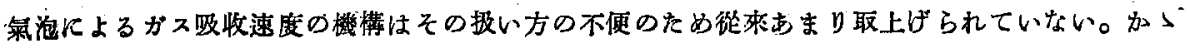

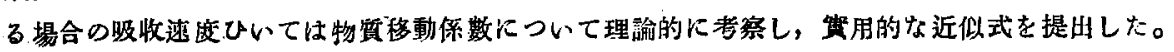

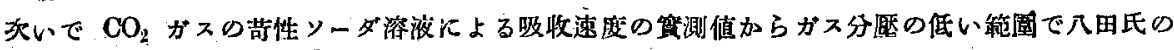

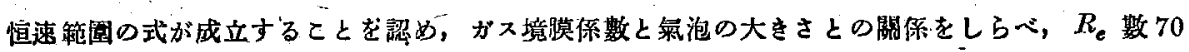

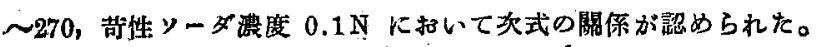

$$
k_{g} d / D^{\prime}=0.0063(d u \rho / \mu) 0.83
$$

\section{(I) 緒 言}

ガス体力淗泡狀をなして液体中を上帠しつつあるさい の吸收速度及びその機構ば一般に広く便用される四收裝

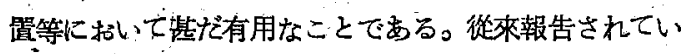
る゙ガス吸收の呼究に括いては，海一ガス接触面の限られ た状態に括ける夜收速度，或は充㙐嗒等による綜合的事 実のみであつて，最基本的と考えられる氣泡によるガ ス吸收速度に閶しては取扱いの不便のため殆儿ど明究さ れて括らず，報文む2，3にとどあるょうである。

Ledig \& Wearer,7) 箕作新六氏日)等の炭酸がスの氣泡

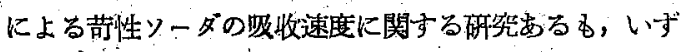
れる炭酸ガスのみの小なる氣泡について行つたるので, 混合ガス及び相当大きな㴋泡の場合に應用するこ亡はで きない。大山義年氏11)12》13）及びその共闰咞究者等に よる一連の氣泡狀ガスの吸收に関する興味ある的筑があ るが，物質係数の取报い方に難点があるのでがる場 合の取扱い方並びに赥性シーダによる炭酸ガスの吸收速 段についての測定結果を報告する。

\section{(II) 理論的考察}

ガス吸收速度の理諭について良一般に Lewis-Whitman 8) の2 重境膜說为堔用される。今ガス境膜に刘し て昖散の法則を適用すると次の如くになる。

$$
\begin{aligned}
\frac{d W}{A d \theta}=\frac{D_{g}}{t_{g}} & \frac{P}{P-p_{a v}}\left(p_{g}-p_{i}\right) \\
& =k_{q} \frac{P}{P-p_{a v}}\left(p_{q}-p_{i}\right)
\end{aligned}
$$

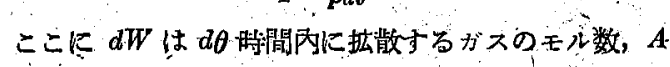

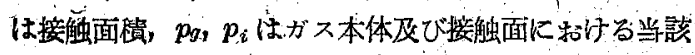
ガスの分压, $P$ はガスの全圧, $p_{a v}$ は $p_{g}$ と $p_{i}$ との算
術本均值で， $t g$ は氣境膜の厚さ， $D_{0}$ は萿当な單位であ らわした拡散保数で， $k_{q}$ はガス境荧係数である。

今笚一氣泡に上るガス四收の塨合を考党るに，吸收の 淮行つれて被吸收ガスの分圧 $p_{g}$ は減少しかつ接触面積 $A$ もともに变化し，さらに氣泡の上卓に件方膨脤をる考 虑しなければならない。

\section{1. 氣泡上羿に伴う靜圧娍少の吸收速度式に对する影 帮}

氯泡上犁のための作棈の膨張に伐亏接触面棈の变化は，


要形を扢こさないるのとすればあきらかに垡面皘の变 化率は体積变化率の $2 / 8$ である。即方

$$
\Delta A-\frac{2}{A} \frac{\Delta}{V}
$$

，通常氣泡式ガス吸收裝置は圧提失大なるため小型のる のが多く, 液高も1 $\mathrm{m}$ 以下と考えられるので, この液高

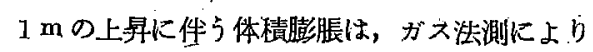

$$
\frac{\Delta \vec{V}}{V}=-\frac{\Delta P}{P}
$$

大氣压は水柱 $10.34 \mathrm{~m}$ なることを䑁えて

$$
100\left(-\frac{\Delta V}{V}\right)=-10 c\left(\frac{\Delta P}{P}\right)=-\left(\frac{100}{10.34+1}\right)=-8.85 \%
$$

これによる表面皘に䴔する影響は $(8.85)(2 / 3)=5.9 \%$

であ。

以上は氣泡上泉に上る接触面穞の变化のみ考考察した のであるが，被吸收ガスか液に非常に溶解しやすい場合 には液境膜の担抗汴殆しど無視し得て $p_{i}=0$ 之考穴ら れるから、この関係及びガス法則 $p_{g} V=n R T$ を(1)に スれて被吸收ガスか稀溥な場合には

$$
\frac{d W}{d \theta}=k_{q}\left(\frac{A}{V}\right) n R T
$$




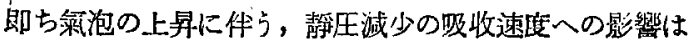
$(A / V)$ なる項考蔡すべきことんなる。今溫度一定と 見做して $(A / V)$ の変化を考觉るにこれを $K$ 置いて

$$
\begin{aligned}
& K=\frac{A}{V}=\frac{2 \pi d^{2}}{1 / 6 \pi d^{3}}=\frac{12}{d} \\
& \frac{\Delta K}{\Delta V}=\frac{\Delta K}{\Delta d} \cdot \frac{\Delta d}{\Delta V}=\left(\frac{-12}{d^{2}}\right)\left(\frac{6}{3 \pi d^{2}}\right)(1-5) \\
& \therefore \Delta K=\left(\frac{-12}{3 d}\right)\left(\frac{\Delta V}{V}\right)
\end{aligned}
$$

(1-4)，(1-6)式より

$$
\frac{\Delta K}{K}=-\frac{1}{3}\left(\frac{\Delta V}{V}\right)
$$

即ち，体棈变化の制合の $1 / 3$ となり，前にならつて液高 $1 \mathrm{~m}$ にいて $(A / V)$ の変化率は $2.95 \%$ あつて $(A / V)$ は実驗誤差筙囲內で一定と考えてさしつか充ないよつ て以下氯泡の上䒜に上る静圧減少の四收速度式一の影留 は考琶しないこととなる。

\section{2. 氣泡によるガス兴收速度式}

ガス吸收速度の一般式11に执いて，来泡による吸收の 場合は $A, p_{g}$ 及び $k_{g}$ は求泡內の被吸收ガスのモル数の 函数であつて，これを解く場合これらをそれぞれ被吸收 ガスのモル数 $W$ の函数として表わす必要がある。

モル数 $W$ と表面棈 $A$ との間にはガス法則より体債 $V$ はモル数に比例し，さらに体䞍 $\mathrm{V}$ は氣泡の徑の 3 乘に，

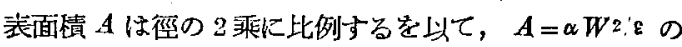
関係がありここにいは形状係数なる恒数である。な 抢通常のガス吸收では不活性ガスが存在する。これは吸 收の盲後に捣、こ变らない故恒数と見做され，これを とすれば一般に

$$
A=\alpha \cdot(W+a)^{2 / s}
$$

さらにモ゙数 $W$ と分圧 $p_{g}$ との閣には次の関係が西 る。

$$
p_{g}=\left(W / W^{\prime}+a\right) P
$$

よつてこれらの関倸を(1)式に代入し雨辺を $W$ の函数と して裴わせば染泡によるガス吸收速度を表わす関係式が 得られる筈である。しかしこの場合式が腹雜化し実用に 供し得ない。よつてかつる氣泡によるガス吸收荎; 被吸

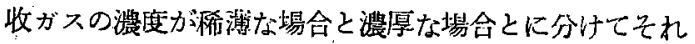
ぞれ近似解を求めることつする。

a) 被吸收ガスが稀薄な場合稀溥ながス空吸收さ せる場合にはガスの溶解に伴う接触面積の变化はごく小 さく㳯面棈は一定と考えられるのでれれ $A_{\eta}$ と置くこ とができる。かつの場合 $\left(P / P-p_{a v}\right) 1$ にして吸 收速度式は次の上弓に表わされる。

$$
-d W=k_{g} A_{m} \Delta d \theta
$$

ここに $\Delta=p_{g}-p_{i}$ である。

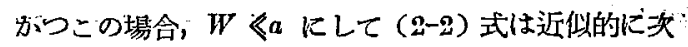
式の如くなる。

$$
\boldsymbol{p}_{\boldsymbol{g}}=\frac{W}{a} \boldsymbol{P}
$$

上式に括いて $a, p$ は恒数なるを以工 $p_{g}$ は $W$ K比 例することななり，即ち $\beta$ 尤比例恒数とすれば

$$
p_{g}={ }^{-} \beta W \text {. }
$$

よつてこの関係を(2-3)式に代入し両辺を精分して变 形当を（ $p_{i}$ は一定と考えて $)$

$$
W_{0}-W \doteq k_{g} A_{m} \dot{\Delta}_{m} \theta
$$

但L $\Delta_{m_{*}}=\frac{p_{g_{0}}-p_{g}}{\ln \frac{p_{90}-p_{i}}{p_{g}-p_{i}}}$

ここに $p_{g_{0}}$ は吸收開始特に特ける被吸收ガスの分圧， $p_{g}$ は $\theta$ 牌閒後の分圧である。即ち $\triangle_{m}$ は分圧差の刘数

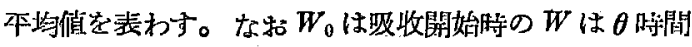
後の被吸收ガスのモル数である。

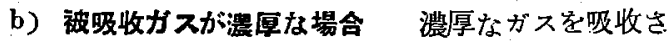
せる場合には吸收に件う氣泡中の被吸收ガスの分圧の变 化は僅にして $\left(p_{g}-p_{i}\right)$ は吸收の前後に批いて二定また はそれに近いるのと考克られ， $\Delta_{m}$ を以てこれを示方 のとす。な招 $k_{g}\left(P / P-p_{a v}\right)$ \& $p_{a v}$ は一定と見倾され るので恒数として取报われる。为つ接触面皘 $A$ は (2-1) 式において $W \gg a$ の場合に相当し，即ち被吸收ガスの みを考慮すればよいことになる。從つて吸收涑度式は

$$
-d W=\dot{k_{g}} \frac{P}{P-P a v} \alpha W^{2 / 3} \triangle_{n} \cdot d \theta
$$

これを積分して変形し，かつ $W_{0}-W=1 / \alpha^{3 / 2}\left[A_{0}{ }^{3 / 2}-\right.$ $A^{3 / 2}$ ]なる関係を用いると炏式を得る。

$$
\begin{aligned}
& W_{0}-W=A_{m} k_{g} \frac{P}{P-p_{a v}} \Delta_{m} \theta \\
& \text { 但し } A_{m}=\frac{1}{3} \frac{A_{0}^{3 / 2}-A^{3 / 2}}{A_{0}{ }^{1 / 2}-A^{1 / 2}} .
\end{aligned}
$$$$
(2-9)
$$

c）一般的な堷合の近以式，被吸收ガ八の分圧の小 ぜ場合には裴面積一定之見做して分压の变化のみを考 濾し，分压差の本均值として対数平均倬を使用すればよ く，一方被吸收ガンの分圧の大なる时は分压は殆ど变化

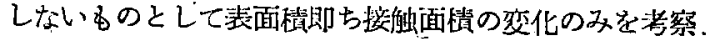

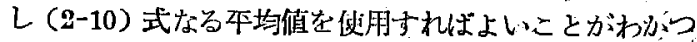
たのである。

一般的な場合の吸收に执いてはこの両者意組合せて四

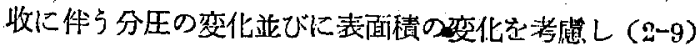

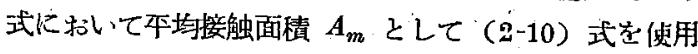
し，分圧差の平均值 $\Delta_{m}$ として (2-7) 式の対数平均值 岂採用严れば工学的の計算には用い得る゙と考えるが，上 


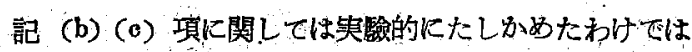
ない。

\section{（III） 苛性ソーダによる㞸酸ガスの吸收}

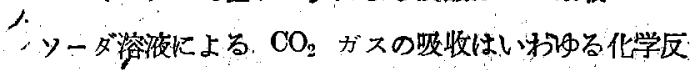

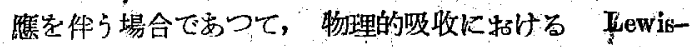
Whitman のっ重境膜說を艺のす与適用することはでき ない。これについては從來多くの研究方行われて和りそ の反應楼棈も明がされている。なかでる注目すべきは

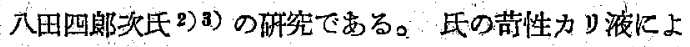
る炭酸ガ入吸收の研究によれば，

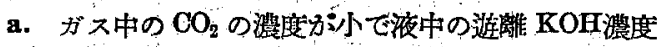
カ九大な尚場合には吸收速度は略々ガス中の $\mathrm{CO}_{2}$ の分厈 に比例し KOH の澧度に関係しない。即ち吸收速度は

$$
\frac{d W}{A d \theta}=k_{g} p_{g}
$$

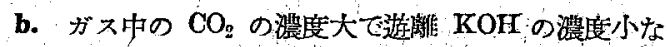
る場合には KOH の澧度小なる程吸收速度は娍少し, 吸

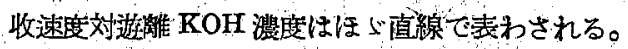

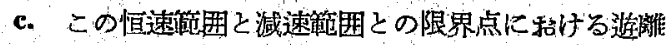
濃度凹は次式で示される

$$
x=C_{K}-\frac{C}{2}=2\left(\frac{k_{g}}{k_{l}}\right) p_{g}
$$

但し $\sigma_{K}:$ アルカリ液中の加里の清度 $(\mathrm{mol} / \mathrm{l})$

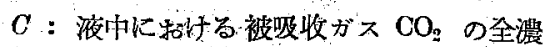
度 $(\mathrm{mol} / \mathrm{l})$

な牯氏はこの結果をその方节性ソーダ液炕適用する には疑問の余地があるとしているが，その後Jennyのは は 八田氏と同榜な実驗を繰返 し NaÔH 溶液による塲合に

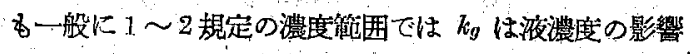
一を受けないことを礁めている。

以上の結果苛性〉ーダ液炕よる $\mathrm{CO}_{2}$ の吸收に和いて はある濃度籍国で $\mathrm{CO}_{2}$ の分压の低儿場合々限り吸收速 度はガスの分圧に比例し，いわゆる Lewis-Whitinan の一般式に括いて $p_{i}=0$ と置いた関保式が成立するこ と莎考它机る。

: 匊泡に上るガス吸收の場合氣泡の大ささによつて吸收 速度にい方なる影製を受けるかは吸收操作の点からすま た氣泡の運動に伴い氣泡远形成している境膜が液中を上

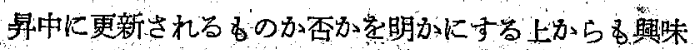

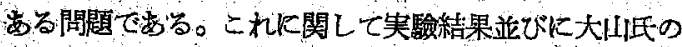
データを使用し，前述した関任式によつて結果を检討す ๖.

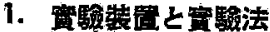



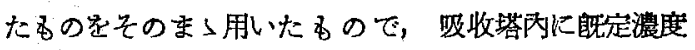
(0.1N) の苛性ソーダ液安一定高さまで充し，一定割合

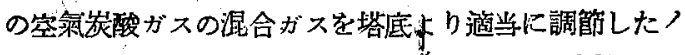
ズルより氣泡を発生させ液中を上㸝する間に $\mathrm{CO}_{2}$ ガス 在吸收させたるのである。氣泡発生時中の $\mathrm{CO}_{2}$ の吸收 をさけるためノズル口端昆水銀中につけ水銀中で氣泡を 発生させ, 水銀面办らの高させ以て吸收液柱の高さとし た。氣泡の火きさはフズルの調簛によつて行い，フズル の位置飞括ける氧泡の大きさとしては比較的大きなるの につ、ては大山氏の実測があるので，0.2 0.07 cc の閒

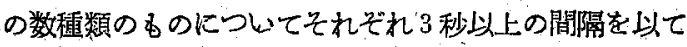
発生させ，発生氣泡の均一性と氮泡相互による撜抖効果 をさけた。

吸收の淮行狀熊をみるため液高を 20 ～80 cm の間完数

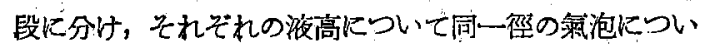
て实驗を繰返した。

液中定上昇中に吸收されすに残留した $\mathrm{CO}_{2}$ ガスはガ ス受けに褀集し，これが補集中级吸收作用の進行するの を避けるため，ガス受け內の液面老少量の石油脱で雨り た。約 300 500 個の氣泡を集め Hempel の分析裝置に 上つて残留 $\mathrm{CO}_{2}$ ガスを求めた。な招吸收に括ける單一。



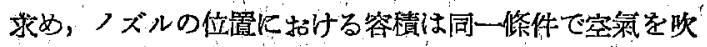

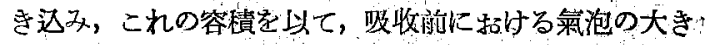
さとした。

\section{2. 結果とその考察}



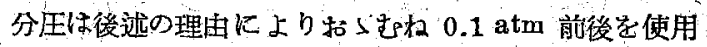
し，氣泡径 4 種につき，液高者 $20,40,60,80 \mathrm{~cm}$ に 变じて行つた。

実驗結果招上 び必要な計算結 果老 Table 1

(次頁) に示L た。察招，大山 氏の図表より求 めを值より再計 算した結果をる 件記した。同表 中残留 $\mathrm{CO}_{2} \mathrm{~mol}$

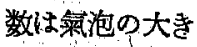
巳乙 $\mathrm{CO}_{2}$ 分压と から計算によつ て求めたるのて 
Table. 1

(Concentration of $\mathrm{Na} 6 \mathrm{H} 0.1 \mathrm{~N}$; Temp. $15 \sim 20^{\circ} \mathrm{O} ; D^{\prime}[\mathrm{gmol} / \mathrm{cm} \cdot \mathrm{hr}] * 2.64 \times 10^{-2}$ )

\begin{tabular}{|c|c|c|c|c|c|c|c|c|c|c|c|c|c|}
\hline $\begin{array}{l}\text { Run } \\
\text { No. }\end{array}$ & $\begin{array}{c}\text { Size } \\
\text { of } \\
\text { bubble } \\
\text { at } \\
\text { nozzle } \\
\text { cc }\end{array}$ & $\begin{array}{c}\text { Heikbt } \\
\text { of } \\
\text { Jiquid } \\
\text { civ }\end{array}$ & $\begin{array}{c}\text { Size } \\
\text { of } \\
\text { bubble } \\
\text { at } \\
\text { the top } \\
\text { ce }\end{array}$ & $\begin{array}{c}\text { Equivalent } \\
\text { diameter } \\
\text { (mean) } \\
d \\
\text { cin }\end{array}$ & $\begin{array}{c}\text { Velocity } \\
\text { of } \\
\text { bubble } \\
u \\
\mathrm{cin} / \mathrm{sec}\end{array}$ & $\begin{array}{c}\text { Ilime } \\
\text { of } \\
\text { rising } \\
\theta \\
\text { sec }\end{array}$ & $\begin{array}{c}\text { PartiaI } \\
\text { press. } \\
\text { of } \mathrm{CO}_{2} \\
p_{g} \\
\times 102 \\
\text { afwa }\end{array}$ & $\begin{array}{c}\text { Residus } \\
\text { ofv } \\
\mathrm{CO}_{2} \\
\times 106 \\
\times 106 \\
\text { mol }\end{array}$ & $\begin{array}{c}\text { Surface } \\
\text { area } \\
(\text { nean) } \\
A \\
A \\
\mathrm{~cm}^{2}\end{array}$ & $\begin{array}{r}k \\
\mathrm{~mol} / \mathrm{cm} \\
\times 10^{2}\end{array}$ & $\begin{array}{l}\text { meatm } \\
\text { mean. }\end{array}$ & $\begin{array}{c}k_{g} d / D^{\prime} \\
\times 10\end{array}$ & $d u \rho / \mu$ \\
\hline 1 & 0.073 & $\begin{array}{l}0 \\
20 \\
40 \\
60\end{array}$ & $0070^{+}$ & 0.518 & 20.4 & $\begin{array}{l}0 \\
0.98 \\
1.96 \\
2.94\end{array}$ & $\begin{array}{l}6.0 \\
2.9 \\
1.3 \\
0.6\end{array}$ & $\begin{array}{l}0.196 \\
0.092 \\
0.040 \\
0.018\end{array}$ & 0.846 & $\begin{array}{l}1.065 \\
1.10 \\
1.08\end{array}$ & 1.080 & 2.12 & 73.8 \\
\hline 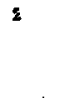 & $0.09 \Sigma$ & $\begin{array}{l}0 \\
20 \\
40 \\
60\end{array}$ & $0.088^{+}$ & 0.560 & 20.85 & $\begin{array}{l}0 \\
0.96 \\
1.92 \\
2.88\end{array}$ & $\begin{array}{r}10.5 \\
5.3 \\
2.7 \\
1.3\end{array}$ & $\begin{array}{l}0.431 \\
0.206 \\
0.102 \\
0.048\end{array}$ & 0.986 & $\begin{array}{l}1.12 \\
1.09 \\
1.10\end{array}$ & 1.103 & 2.34 & 81.9 \\
\hline 3 & 0.180 & $\begin{array}{l}0 \\
20 \\
40 \\
60\end{array}$ & $0.175^{+}$ & 0.700 & 21.0 & $\begin{array}{l}0 \\
0.95 \\
1.90 \\
2.85\end{array}$ & $\begin{array}{l}8.6 \\
5.0 \\
2.8 \\
1.5\end{array}$ & $\begin{array}{l}0.691 \\
0.387 \\
0.442 \\
0.112\end{array}$ & $\begin{array}{l}1.540 \\
-\end{array}$ & $\begin{array}{l}1.13 \\
1.11 \\
1.2 .1\end{array}$ & 1.130 & 3.00 & 103 \\
\hline 4 & 0.206 & $\begin{array}{r}0 \\
20 \\
i 0 \\
60 \\
80\end{array}$ & $0.107^{+}$ & 0.732 & 21.3 & $\begin{array}{l}0 \\
0.94 \\
1.88 \\
2.82 \\
3.76\end{array}$ & $\begin{array}{l}9.4 \\
6.5 \\
3.19 \\
1.93 \\
.1 .00\end{array}$ & $\begin{array}{l}0.860 \\
0.491 \\
0.274 \\
0.163 \\
0.084\end{array}$ & 1.682 & $\begin{array}{l}1.13 \\
1.16 \\
1.13 \\
j .18\end{array}$ & 1.150 & 3.19 & 109 \\
\hline $6^{*}$ & 0.48 & $\begin{array}{r}.0 \\
59 \\
91 \\
122 \\
154\end{array}$ & $\begin{array}{l}0.49 \\
0.42 \\
0.42 \\
0.42 \\
0.42\end{array}$ & 0.93 & 24.4 & $\begin{array}{l}0 \\
2.4 \\
3.65 \\
5.0 \\
6.25\end{array}$ & $\begin{array}{l}23.6 \\
8.06 \\
4.0 \\
2.52 \\
1.6^{3}\end{array}$ & $\begin{array}{l}6.0 \\
1.70 \\
1.00 \\
0.50 \\
0.30\end{array}$ & 2.72 & $\begin{array}{l}1.21 \\
1.22 \\
3.06\end{array}$ & 1.16 & 4.08 & 159 \\
\hline$B^{*}$ & $0 .-5$ & $\begin{array}{r}0 \\
59 \\
91 \\
122 \\
154\end{array}$ & $\begin{array}{l}0.75 \\
0.66 \\
0.66 \\
0.66 \\
0.66\end{array}$ & 1.08 & 25.4 & $\begin{array}{l}0 \\
2.30 \\
3.50 \\
4.75 \\
6.00\end{array}$ & $\begin{array}{c}23.6 \\
8.70 \\
6.87 \\
3.50 \\
2.34\end{array}$ & $\begin{array}{l}9.4 \\
2.90 \\
1.90 \\
1.15 \\
0.70\end{array}$ & 3.66 & $\begin{array}{l}1.21 \\
1.23 \\
1.22\end{array}$ & 1.22 & 5.00 & 192 \\
\hline $7^{*}$ & 1.17 & 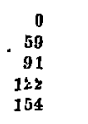 & $\begin{array}{l}1.17 \\
1.03 \\
1.03 \\
1.03 \\
1.06\end{array}$ & 1.26 & 26.6 & $\begin{array}{l}0 \\
2.25 \\
3.40 \\
4.50 \\
5.75\end{array}$ & $\begin{array}{c}23.6 \\
8.23 \\
6.32 \\
3.62 \\
2.45\end{array}$ & $\begin{array}{r}14.8 \\
4.30 \\
2.70 \\
1.80 \\
1.20\end{array}$ & 4.90 & $\begin{array}{l}1.36 \\
1.26 \\
1.17\end{array}$ & 1.26 & 6.02 & 234 \\
\hline $8^{*}$ & 1.61 & $\begin{array}{r}0 \\
59 \\
91 \\
122 \\
164\end{array}$ & $\begin{array}{l}1.61 \\
1.45 \\
1.42 \\
3.42 \\
1.45\end{array}$ & 1.40 & 27.6 & $\begin{array}{l}0 \\
2.10 \\
3.28, \\
4.40 \\
5.58\end{array}$ & $\begin{array}{c}23.6 \\
9.66 \\
6.03 \\
3.90 \\
2.75\end{array}$ & $\begin{array}{r}20.2 \\
7.00 \\
4.20 \\
2.63 \\
1.86\end{array}$ & 6.10 & $\begin{array}{l}1.68 \\
1.40 \\
1.22\end{array}$ & 1.30 & 6.90 & 270 \\
\hline
\end{tabular}

Riote; * No. 6-8 are recalculated from the Oyana's chart.

** Values given in the "Principles of Chem. Kay, p. 160 " are corrected by temperature.

+ As the uniformity of volume at each height of liquor is prestuned from the values of No. B 8, No. 1 4 are measured for the case of the height of $40 \mathrm{ccs}$.

ある。

1）表面辕 ノズルよりガス受け器の液面までの高 さと氯泡の大きさ関係を大山氏のデータによつて示 すと Fig. 1 の如くなる。ノズルを出て上昇し初めた氣 泡はかなり炭酸ガスの分圧高く吸收に件つて濑沃小とな るが，一定特間をすぎるとほが一定の值を示すに至る。 即ち稀薄ガスになれば㖟收による少量の体禎縮少と，逆 に靜庄隇少による氣泡の膨脤とが互に相殺し合つて一定

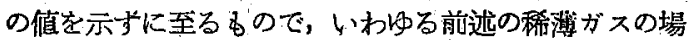
合に特ける武闻皘 A の一定なる仮定が页当なることを， 示するのである。

2) 吸收時間と分圧との関係 $\mathrm{CO}_{2}$ の分圧の小さい

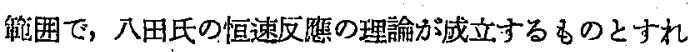

ば，吸收速度は $\mathrm{CO}_{2}$ の分圧に比例することっなり，即 ち $p_{i}=0$ Kして (2-5) (2-6)(2-7)式より次式を得る。

$$
\text { - } \ln \frac{p_{g_{0}}}{p_{g}}=\beta k_{g_{1}} A_{m} \theta
$$

ここに $\beta, k_{g}$, 及び $A_{m}$ は同一氣泡については恒数と考 光られるか. $5 \mathrm{CO}_{2}$ 分压と吸收時間余片対数方眼紙に点 䌡すれば直線となるべきである。その結果を Fig. 2 に 示す。これより明なる如く $\mathrm{CO}_{2}$ 分圧 0.1 atm 上下では この関倸は流よ゙直線となり，吸收速度は分圧に比例しい わゆる恒速筑囲にあること明白である。

3）物啠移動係数（ガス境膜俰数）一定の氣泡に ついで境膜俰数 $k_{g}$ を求める場合 $\mathrm{CO}_{2}$ 分压の高い所 より低分压までー焃化檢討することは上述の結果から見 


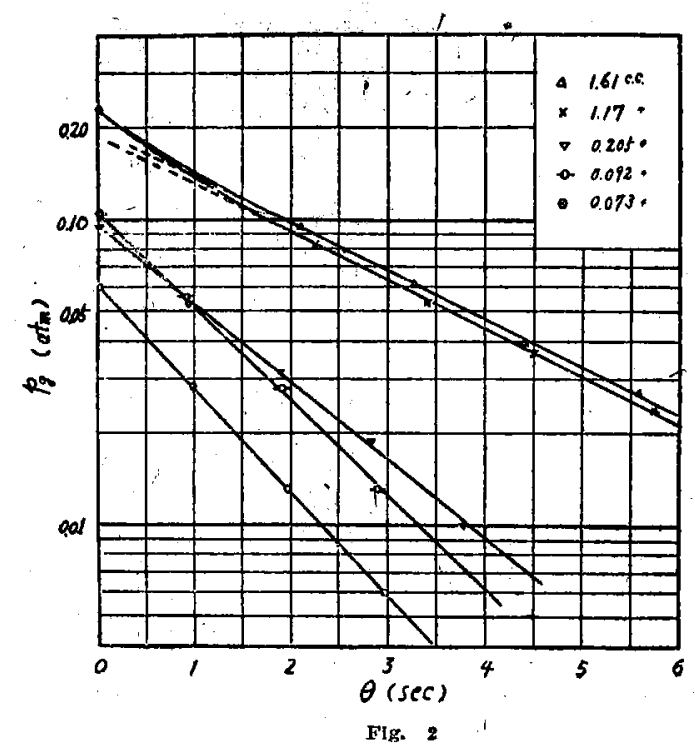

Table 2

1 Gas.film coefficients of, $\mathrm{CO}_{2}$ absurption by sodium hydroxide solution.

\begin{tabular}{|c|c|c|c|c|c|}
\hline Investigator & $\begin{array}{c}\begin{array}{c}\text { Method } \\
\text { of } \\
\text { exporiment }\end{array}\end{array}$ & $\begin{array}{c}\text { Nornality } \\
\mathrm{N}\end{array}$ & $\begin{array}{c}\text { Temp. } \\
{ }^{\circ} \mathrm{C}\end{array}$ & $\underbrace{k}_{[\mathrm{ghrol} / \mathrm{cm}}$ & $\begin{array}{l}k_{g} \\
a^{2} \text { Lr atmin }\end{array}$ \\
\hline Hitcheock & $\begin{array}{l}\text { Batch } \\
\text { Agitation : } \\
\quad 80 \text { r.p.nl. }\end{array}$ & $\begin{array}{l}0.1 \\
0.25 \\
0.5\end{array}$ & 30 & $\begin{array}{l}0.04 \times \\
0.08 \\
0.14\end{array}$ & $\begin{array}{c}10-2 \\
" \\
"\end{array}$ \\
\hline $\begin{array}{l}\text { Davis \& 1) } \\
\text { Crandal] }\end{array}$ & $\begin{array}{l}\text { Batch } \\
\text { Agltation : } \\
\quad 400 \text { r.p.w. }\end{array}$ & $\begin{array}{l}0 \\
0.1 \\
0.25\end{array}$ & 25 & $\begin{array}{l}0.034 \\
0.078 \\
0.14\end{array}$ & ", \\
\hline Jenny 6) & $\begin{array}{l}\text { Fatch } \\
p_{g=0.05 a t m} \\
" 00.08 \\
" \quad \text { o.0s }\end{array}$ & $\begin{array}{l}0.25 \\
0.30 \\
1.0\end{array}$ & . & $\begin{array}{l}\cdot \\
0.68 \\
0.03 \\
2.2\end{array}$ & ": \\
\hline Oyama ${ }_{\text {O Iwase }}$ & $\begin{array}{l}\text { Bubble } \\
\qquad \begin{array}{c}y=1.3 \mathrm{cc} \\
" 1.3 \\
" 1.64\end{array}\end{array}$ & $\begin{array}{l}0.01 \\
0.1 \\
0.25\end{array}$ & 30 & $\begin{array}{l}0.34 \\
1.57 \\
2.84\end{array}$ & "" \\
\hline Author & 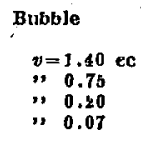 & $\begin{array}{l}0.1 \\
0.1 \\
0.1 \\
0.1\end{array}$ & 20 & $\begin{array}{l}1.30 \\
1.22 \\
1.15 \\
1.08\end{array}$ & ", \\
\hline & 1 & $1 \ldots 1$ & & & \\
\hline
\end{tabular}

ても不都合であつて，低分压即ち 0.1 atu 为下の場合に ついて稀溥がスの場合の近似式 (2-7) を用いて $k_{g}$ をそ れぞれ算出すると各区間に怙いてほら゙一定の值を示す。 少結果に不搠いの点のあるのは実驗誤差並びにグラフ の院みに基く誤差によるるのと考えられる。

“ちろんこの算出に使用した表面倩は，氣泡を球形々 して求めたるので，傎の單位面積当りの吸收速度学現す すのではないが，氣泡相当值径が本実驗籍囲內に特いて



は，泡形は略相似と取报つて差支えないと思われる。 次に氣泡の大きさどガス境膜係数との関係をみるため 対数方眼紙上に值径 $d$ と $k_{g}$ とを点綴すると直線関保が 認められ，次の関保式が得られる。

$$
k_{g}=1.2 \times 10^{-2}(d) 0.11
$$

この結果名從來の交献と比較与をと Table 2 の如く なる。表中回分方法々は平面接触に上るガス吸收実驗で これらの結果と著者並びに大山氏の結果を比較するとそ れぞれ氯泡による吸收の場合か擞倍乃至十数倍大きな值 を示している。

な技彙泡狀吸收に拘いても著者の値と大山氏の值との


$\mathrm{CO}_{2}$ 残留モ儿数対暲間の関係を示したグラフよりアスカ ニア微分器によつて吸收速度 $d W / A d \theta$ を求め, 矢いて $d W / A d \theta$ 対 $p_{g}$ 点経し直線部分索 1 氣圧亩で補外して 求めたものであつて， $d W / \boldsymbol{A} d \theta$ 刘 $p_{g}$ 禃線関係宗主 のは大山氏の図からも明かなように $\mathrm{CO}_{2}$ 分王が $0.1 〜$ 0.2 氣压以下であつて，これを1氣圧まで補外すること は相当誤差の入る可能性办洘光られる。

以上の結果埭泡式は回分法に較べて吸收速度即ちガス

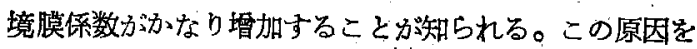
筆者は氣泡の上景運動に件つてガス境膜かれ、ちら゙るしく 更新されるこ之によるるのと考える。

\section{4) ガス境膜保数 $k_{g}$ とレイノルス数 $R_{e}$ との関保}

氣泡の $R e$ 数として $\mu$ 及び $\rho$ にはそれぞれ空氣の値を 探用して Re 数を求め，次いで Sherwood 数 $\left(k_{g} d / D^{\prime}\right)$ 得算出すると.Table 1 の如くなる。この際㧓散係数 $D^{\prime}$ は $(\mathrm{g}-\mathrm{mol} / \mathrm{cm} \cdot \mathrm{hr})$ の头元空使用すべきである。 $R e$ 数に 対詐して $\left(k_{g} d / D^{\prime}\right)$ を対数方眼紙上に点緅して Fig. 3 を得る。これより関係式を求めると

$$
k g d / D^{\prime}=0.0063(d u \rho / \mu)^{0.83}
$$

な牯： $\mathrm{CO}_{2}$ - 空氣混合ガスのみの実驗ではガスの特性 を考萝した Schmidt 数 $\left(\mu / \rho D_{g}\right)$ の影響をみ、るわけに 
は行かはからた。

いずれにしてを Sherwood 数 $\left(\mathrm{kgd} / D^{\prime}\right)$ 'が Re 数の 0.83 乘に比例する訝実は注目すべきことであるが，本 実驗では $R e$ 数は 70〜270 の範囲にあつて，からる球形 の氣泡の場合には臨界レイフルズ数が少さい所にあるの ではないかと考光られ，八田氏4は液滴によるガス吸 收の場合拡散係数务增大寸ること家認め湿流拡散に上る 影響でするらとしている。

\section{(IV) 結 言}

１）懒泡によるガス吸收に括ける吸收速度の取报い方 をガスの分圧が低いとき仅び高いときについてそれぞれ 理論式を導き，一般の場合に物ける近似式を出した。

2）娎性ソーダ溶液による $\mathrm{CO}_{2}$ ガスの吸收速度の実 驗より低分圧に赫いて上式が成立することを明かにし， かつ八田氏の理論力曧性ソーダ溶液に括いても成立する

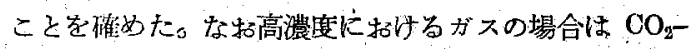
$\mathrm{NaOH}$ 系では八田氏の理論からも明なる如く吸收速度

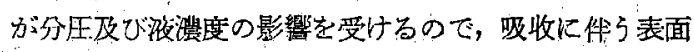
槙の縮少する影響注物埋的吸收の行引れる場合について 改めて試みる予定である。

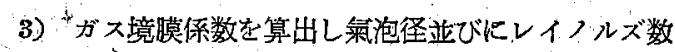
その関倸老明にした。
附記：本研究化掌り御㷂切なる御指導を睗りし恩陑 更京工大内田俊一, 藤田重交教授並びと资料者御提供

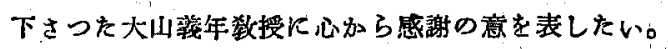

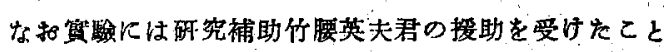
を附記して謝意を表わす。生た文部省科學研究费によ つたことを附記する。

\section{引用文献}

1) Davis, H. S., and G. S. Crandall : J. Am. Chem. Soc, 52 3757,3769 (1930).

2）八肘四郎次 工化 31，869 (1928)；任学機被年報 1 (昭12) 69

3) " "32, 809 (1029)

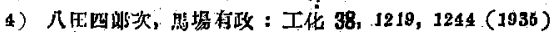

b) Hitchcock, I. B. : Ind. Inng. Chem., 26, 1169 (1984).

6) Jenny, F. J. : Thesis in Chemical Engineering, M. I. Ty; (1936.) Sherwod, 'T.K. "Absorption and Fatract, tion" p. 216.

7) Ledig, P. G., and E. R. Weaver, r. Am. Chem. Soc., 46 , 660 (1924).

8) Tewis W. K., and W. G. Whituant, Ind. Eng. Chem, 16, 1215 (1924).

9) 筫作新六, 回化 48,53,371, 495 (1927)

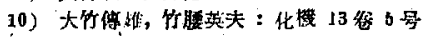

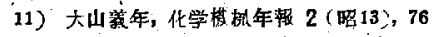

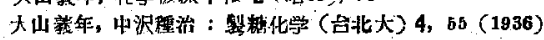
大山義年, 岩粯克已：Sci. Pap. Inst. Phys. Chem. Res., 35 , 131 (1939).

\title{
Absorption Rate of Gas from a Bubble
}

Tsutao Otake.

\author{
Deepartment of Chemical Technology, \\ Faculty of Engineering, Okaka University.
}

\begin{abstract}
The rate equation of gas absorption from a bubble was derived theoritically, and the approximate equation was presented.

Carbon dioxide was absorbed from a bubble using caustic seda solution of $0.1 \mathrm{~N}$, varing the volume of a bubble from 0.2 to 0.07 oc. From the results, the presented approximate equation was verified to be reasonable. The absorption rate observed for $\mathrm{CO}_{2}$ was found to hold the Hatta's theory under the lower partial pressure of $\mathrm{CO}_{2}$, than $0.1 \mathrm{~atm}$, and the rate of absorption was found to be proportional to approximately the 0.83 power of the Reynolds number.
\end{abstract}

